Woman in Russian Society

2021. No. 2. P. 65-79

DOI: $10.21064 /$ WinRS.2021.2.5
Женщина в российском обществе

2021. № 2. C. $65-79$

ББК 60.561 .23

DOI: $10.21064 /$ WinRS.2021.2.5

\title{
WOMEN ENTREPRENEURS IN RUSSIA AND OTHER COUNTRIES: A COMPARATIVE PERSPECTIVE
}

\author{
C. Nechemias ${ }^{\mathrm{a}}$, D. Bahry \\ ${ }^{a}$ School of Public Affairs, Pennsylvania State University, \\ Harrisburg, Middletown, PA, USA, c4n@psu.edu \\ ${ }^{\mathrm{b}}$ Pennsylvania State University, University Park, PA, USA
}

This article addresses gender differences in entrepreneurship in Russia, with a focus on how the Russian case compares with a set of selected benchmark countries. Utilizing primarily GEM data, we examine aspects of entrepreneurial culture, individual attitudes and resources, rates of entrepreneurship, and barriers to starting a new business.

Key words: Russia, gender, female entrepreneurship, gender differences, gender equality, small and medium sized business, economic development.

\section{ЖЕНЩИНЫ-ПРЕДПРИНИМАТЕДЬНИЦЫ \\ В РОССИИ И ДРУГИХ СТРАНАХ: СРАВНИТЕДЬНЫЙ АНАЛИЗ}

\author{
К. Нечемиас ${ }^{\mathrm{a}}$, Д.Бари \\ а Школа по связям с общественностью, Университет штата Пенсильвания, \\ г. Гаррисберг, Миддлтаун (Пенсильвания), США, c4n@psu.edu \\ ${ }^{\mathrm{b}}$ Университет штата Пенсильвания, Университетский парк (Пенсильвания), США \\ Рассматривается участие российских женщин в предпринимательской деятельно- \\ сти в сравнении с участием в ней женщин ряда зарубежных государств. В исследовании \\ использованы данные международного мониторинга предпринимательства (Global \\ Entrepreneurship). Изучены гендерные аспекты, динамика, достижения и проблемы жен- \\ ского предпринимательства. Авторы пришли к выводу, что, несмотря на высокий уро- \\ вень образования и опыт профессиональной деятельности, женщинам не хватает
}

(C) Nechemias C., Bahry D., 2021 
уверенности в своих способностях начать и вести собственное дело, сказывается недостаток информации и знаний в области предпринимательства. Отмечается, что правительство России придает большое значение этой проблеме, меры государственной поддержки женщин содержатся в Национальной стратегии действий в интересах женщин на 2017-2022 гг. Однако, по мнению авторов, период коронавирусной пандемии крайне отрицательно повлиял на состояние малого и среднего предпринимательства. Еще одной проблемой недостаточного участия российских женщин в предпринимательской деятельности является необходимость создания баланса между работой и семейными обязанностями. Среди факторов, способствующих развитию женского предпринимательства, отмечаются влияние компьютеризации на сектор малого и среднего бизнеса, доступность платформы для электронной торговли, использование STEM-технологий, а также возможность повысить уровень профессионального образования с помощью проекта «Women Digital Academy», который совместно реализуют Google России и Комитет по развитию женского предпринимательства «Опоры России». Авторы предлагают комплекс мероприятий по развитию женского предпринимательства, что может способствовать экономическому росту и повышению уровня благосостояния населения.

Ключевые слова: Россия, гендер, женское предпринимательство, гендерные различия, гендерное равенство, малый и средний бизнес, экономическое развитие.

Research on entrepreneurship in Russia's SME (small and medium sized enterprises) sector not only attracts academic interest but carries increasing political and economic weight. As evidence, consider that in 2018, President Putin elevated the sector's standing by including the growth of SMEs in his 12 national projects aimed at transforming Russian society. Moreover, his 2018 presidential address to the Federal Assembly set the ambitious goal of raising the contribution of the SME sector from $20 \%$ of GDP to over $40 \%$ in 6 years [Putin, 2018a: 23-24]. That would bring Russia closer to, though still lagging, Organization for Economic Co-operation and Development (OECD) benchmark countries. In a 2013 Report, the OECD noted that Russia's SME sector contributed $23 \%$ of GDP, while comparable scores for OECD countries ranged from $48 \%$ to $71 \%$ [Russia..., 2013: 20]. The recent trajectory offers little encouragement, with Russia's SMEs contributing $19 \%$ of GDP in 2014 [Feinberg, 2019], $22 \%$ in 2017, and $20 \%$ in 2018 [Russia's Small Businesses... , 2020].

If this situation is to be rectified, increasing the number of women-owned businesses can play a major role. There is growing international recognition that encouraging female entrepreneurship contributes significantly to economic growth, job creation, and poverty reduction. However, cross-national research on gender and entrepreneurship typically finds a gender imbalance: entrepreneurship skews male (cf.: [The Missing Entrepreneurs..., 2019]). Russia has also experienced an imbalance, with different measures suggesting that women make up between 27 and $37 \%$ of entrepreneurs in small/medium businesses [Development of Women's Entrepreneurship..., 2017]. An enhanced understanding of the ways in which Russia's SME sector is "gendered" thus contribute to a rich body of research and also highlight policies that could boost women's successful SME involvement. To tackle this project, we expand on earlier efforts to place the Russian case in a cross-national framework, highlighting commonalities and distinctiveness regarding Russia's SME sector, with special 
emphasis on gender patterns [Djankov et al., 2005; Tsyganova, Shirokova, 2010; Elam et al., 2019; Pin'kovetskaia, 2019].

We rely primarily on GEM (Global Entrepreneurship Monitor) data, with additional evidence from a range of other sources. GEM is an international consortium of leading business schools that conducts regular, cross-national population surveys (APS) with samples of at least 2000 adults aged 18 to 64. It also asks experts in participating countries to evaluate the national context for entrepreneurial activity ${ }^{1}$. GEM focuses on the early stages of business start-ups and key aspects of the SME ecosystem like a conducive culture, availability of financing, and institutional and infrastructure factors. We explore GEM data on entrepreneurship and gender for the years 2018/2019, a span the World Bank characterizes for Russia as a post-recession return to slow economic growth, prior to the deep slowdown associated with the 2020 global pandemic [Modest Growth..., 2019] ${ }^{2}$. We focus on three groups of countries as benchmarks: France, Germany, the U.K. and U.S. representing high-income Western states: Poland and Slovakia representing Visegrad countries; and Brazil, China and India, representing BRICS ${ }^{3}$.

Utilizing GEM data offers substantial methodological advantages, given its reliance on uniform survey instruments across countries ${ }^{4}$. Moreover, its conceptualization of SMEs as centering on new business activity bypasses the problems associated with the wide variety of country-specific SME definitions. GEM also offers an additional advantage, by including unregistered as well as registered entrepreneurial activity, while official statistics typically refer only to registered SMEs [Acs et al., 2008].

To explore how the Russian SME sector and its gendered patterns compare to benchmark countries, we focus on: the degree to which the public provides a welcoming entrepreneurial culture; the existence of individual social attitudes and resources such as confidence in one's capabilities, personal networks, and fear of failure; and individual perceptions of opportunity and willingness to start new businesses. We then turn attention to the context, or ecosystem for entrepreneurship, and the degree to which it helps or hinders new business development.

\section{Entrepreneurship: a good and high-status career?}

A culture supportive of entrepreneurship strongly influences decisions about whether to launch a new venture. Key issues center on whether the public believes that

\footnotetext{
${ }^{1}$ GEM defines entrepreneurship as any attempt at new business or new venture creation such as self-employment, a new business organization, or the expansion of an existing business. Available from: https://gemconsortium.org/wiki/1149 (accessed 30.07.2019).

${ }^{2}$ We rely here on summary data from GEM project reports. GEM also provides full individual-level survey and expert rating datasets for all countries, with a 3-year lag. As of this writing, the data are available up through 2016. Given the new Russian government emphasis in 2018 on accelerating SME development, we focus mostly on data for that year. Of course, responses to questions can fluctuate from year to year, so our analysis should be considered a snapshot at a key juncture for the SME sector.

${ }^{3}$ The Czech Republic and Hungary, the two other Visegrad countries, did not participate in the GEM wave analyzed here.

${ }^{4}$ Information on the data collection and other details for the adult and expert surveys is available from: https://www.gemconsortium.org/about/wiki (accessed 05.11.2020).
} 
starting a business is a good career choice and carries high status. For Russia, the evidence is mixed: the country has been known for the public's skepticism about business. Indeed, a 2018 poll found that $68 \%$ of Russians thought it was "definitely not" or "probably not" possible to get rich while remaining honest [Kolesnikov, Volkov, 2019: 7]. But views toward private entrepreneurship are more positive, especially toward SMEs. A Levada Center survey showed that $81 \%$ of the public held very good / mostly good opinions about owners of small businesses, a figure that slipped to $78 \%$ for medium-sized firms, and to $57 \%$ for big business and commercial networks [Business, 2014]. Moreover, the public's response to the question of women owners of SMEs appears to be quite positive. According to one report, $93 \%$ of the public in 2016 expressed confidence in women's capacity to head small and medium-sized businesses [Poll..., 2016].

Turning to individual attitudes toward entrepreneurial careers, the data show a relatively high level of approval among both men and women in Russia (Table 1). Approval is gendered, however: among women, $69.9 \%$ approve of entrepreneurship as a livelihood and $74.4 \%$ attach a high status to that choice. Fewer men $(53 \%)$ consider entrepreneurship a good career, and $51.7 \%$ see it as a high-status occupation.

Table 1

Societal attitudes on entrepreneurship

\begin{tabular}{|c|c|c|c|c|c|c|}
\hline \multirow{2}{*}{ Countries } & \multicolumn{3}{|c|}{ A. Good career } & \multicolumn{3}{|c|}{ B. High status } \\
\hline & Men & Women & Ratio W/M & Men & Women & $\begin{array}{l}\text { Ratio } \\
\text { W/M }\end{array}$ \\
\hline Russian Federation & $53.0 \%$ & $69.9 \%$ & 1.3 & $51.7 \%$ & $74.4 \%$ & 1.4 \\
\hline \multicolumn{7}{|l|}{ W. Europe / U. S. } \\
\hline \multirow{4}{*}{$\begin{array}{l}\text { France } \\
\text { Germany } \\
\text { U. K. } \\
\text { U. S. }\end{array}$} & $65.6 \%$ & $72.4 \%$ & 1.1 & $43.1 \%$ & $68.1 \%$ & 1.6 \\
\hline & $61.3 \%$ & $73.4 \%$ & 1.2 & $74.8 \%$ & $76.9 \%$ & 1.0 \\
\hline & $55.2 \%$ & $81.9 \%$ & 1.5 & $74.9 \%$ & $71.5 \%$ & 1.0 \\
\hline & $64.0 \%$ & $77.0 \%$ & 1.2 & $79.0 \%$ & $82.4 \%$ & 1.0 \\
\hline \multicolumn{7}{|l|}{ Visegrad } \\
\hline \multirow{2}{*}{$\begin{array}{l}\text { Poland } \\
\text { Slovak Republic }\end{array}$} & $52.2 \%$ & $54.3 \%$ & 1.0 & $60.9 \%$ & $82.4 \%$ & 1.4 \\
\hline & $48.8 \%$ & $54.8 \%$ & 1.2 & $73.9 \%$ & $72.8 \%$ & 1.0 \\
\hline \multicolumn{7}{|l|}{ BRICS } \\
\hline Brazil & $78.6 \%$ & $22.7 \%$ & 0.3 & $65.7 \%$ & $53.3 \%$ & 0.8 \\
\hline China & $67.5 \%$ & $79.9 \%$ & 1.2 & $67.1 \%$ & $87.4 \%$ & 1.3 \\
\hline India & $18.3 \%$ & $43.5 \%$ & 2.4 & $53.8 \%$ & $47.5 \%$ & 0.9 \\
\hline
\end{tabular}

Source for Tables 1—4: [Elam et al., 2019: 74—99].

Cross-nationally, gender gaps characterize responses to these two questions, often in favor of women. Along with women in Russia, those in several benchmark countries are more likely than men to endorse the view that starting and owning a business constitutes a good and high-status career choice. 


\section{Capability, personal relationships and fear of failure}

Other data, however, suggest that a positive view of business careers does not necessarily translate into stepping forward as an entrepreneur. It can also be important to have confidence in one's skills and knowledge to start a new business, a low fear of failing; and a personal connection to an entrepreneur — such as a friend or family member - who may be a motivator and/or source of encouragement.

Table 2

Personal relationships, capability and fear of failure

\begin{tabular}{|c|c|c|c|c|c|c|c|c|c|}
\hline \multirow{2}{*}{ Countries } & \multicolumn{3}{|c|}{$\begin{array}{c}\mathrm{A} \\
\text { Know an entrepreneur }\end{array}$} & \multicolumn{3}{|c|}{$\begin{array}{c}\text { B } \\
\text { Perceived capability }\end{array}$} & \multicolumn{3}{|c|}{$\begin{array}{c}\mathrm{C} \\
\text { Fear of failure* }\end{array}$} \\
\hline & Men & Women & $\begin{array}{l}\text { Ratio } \\
\text { W/M }\end{array}$ & Men & Women & $\begin{array}{l}\text { Ratio } \\
\text { W/M }\end{array}$ & Men & Women & $\begin{array}{l}\text { Ratio } \\
\text { W/M }\end{array}$ \\
\hline $\begin{array}{l}\text { Russian } \\
\text { Federation }\end{array}$ & $38.8 \%$ & $32.8 \%$ & 0.8 & $33.1 \%$ & $22.2 \%$ & 0.7 & $39.6 \%$ & $49.6 \%$ & 1.3 \\
\hline \multicolumn{10}{|l|}{$\begin{array}{l}\text { W. Europe / } \\
\text { U. S. }\end{array}$} \\
\hline \multirow{4}{*}{$\begin{array}{l}\text { France } \\
\text { Germany } \\
\text { U. K. } \\
\text { U. S. }\end{array}$} & $37.6 \%$ & $28.8 \%$ & 0.8 & $46.2 \%$ & $28.9 \%$ & 0.6 & $33.2 \%$ & $41.3 \%$ & 1.2 \\
\hline & $25.9 \%$ & $21.0 \%$ & 0.8 & $44.6 \%$ & $31.0 \%$ & 0.7 & $33.7 \%$ & $46.0 \%$ & 1.4 \\
\hline & $37.2 \%$ & $29.4 \%$ & 0.8 & $56.5 \%$ & $36.8 \%$ & 0.7 & $37.5 \%$ & $44.0 \%$ & 1.2 \\
\hline & $43.5 \%$ & $33.7 \%$ & 0.8 & $62.1 \%$ & $49.5 \%$ & 0.8 & $37.3 \%$ & $45.4 \%$ & 1.2 \\
\hline \multicolumn{10}{|l|}{ Visegrad } \\
\hline \multirow{2}{*}{$\begin{array}{l}\text { Poland } \\
\text { Slovak } \\
\text { Republic }\end{array}$} & $42.3 \%$ & $37.9 \%$ & 0.9 & $53.8 \%$ & $39.4 \%$ & 0.7 & $38.0 \%$ & $55.6 \%$ & 1.5 \\
\hline & $37.2 \%$ & $32.7 \%$ & 0.9 & $61.0 \%$ & $45.4 \%$ & 0.7 & $32.4 \%$ & $50.6 \%$ & 1.6 \\
\hline \multicolumn{10}{|l|}{ BRICS } \\
\hline \multirow{3}{*}{$\begin{array}{l}\text { Brazil } \\
\text { China } \\
\text { India }\end{array}$} & $40.2 \%$ & $28.7 \%$ & 0.7 & $59.5 \%$ & $49.2 \%$ & 0.8 & $39.3 \%$ & $49.5 \%$ & 1.3 \\
\hline & $46.9 \%$ & $44.5 \%$ & 0.9 & $28.6 \%$ & $19.6 \%$ & 0.7 & $39.4 \%$ & $43.6 \%$ & 1.1 \\
\hline & $36.9 \%$ & $25.9 \%$ & 0.7 & $59.9 \%$ & $43.9 \%$ & 0.7 & $42.4 \%$ & $43.5 \%$ & 1.0 \\
\hline
\end{tabular}

*The question in column $\mathrm{C}$ was asked only of respondents who said they saw opportunities to start a business in their local area in the next 6 months. Column $\mathrm{C}$ percentages and $\mathrm{W} / \mathrm{M}$ ratio have been inverted from their original form in the GEM so that the data her reflect the \% who say "fear" [Elam et al., 2019].

Capability perceptions involve confidence in having the skills and knowledge to start a new business. Not counting respondents already involved in entrepreneurial activity, both male and female respondents in Russia offer a skeptical assessment: only $33.1 \%$ of men and $22.2 \%$ of women believe that they have such capability - figures below the levels typically exhibited by their cross-national peers (Table 2, column B). Thus, despite Russian women's impressive educational and work force credentials, the Russian case follows a common cross-national pattern: in all our cases, men are more certain of their ability to form and run a business than women.

Even with confidence in one's ability, however, fear of failure can prove to be an obstacle to becoming a budding entrepreneur. On this issue, not counting respondents already engaged in their own business, a substantial share of Russian men (39.6\%) and women (49.6\%) who perceive good opportunities for entrepreneurship in their locality express a fear of failing (Table 2, column C). In this respect, they are 
similar on average to counterparts in benchmark countries; and women in almost all of the countries appear to be more concerned than men are about potential business failure.

In addition to self-confidence, social networks inspire individuals to take up entrepreneurship [Djankov et al., 2005]. One indicator of social connection is whether respondents personally know an entrepreneur. For Russia, $38.8 \%$ of men and $32.8 \%$ of women report having a friend or relative who is an entrepreneur. Russia falls in a middling position among our benchmark countries and conforms to the crossnational pattern of men being more likely on average to report having a friend or relative who is an entrepreneur.

\section{Stages of entrepreneurship}

GEM data also provide an opportunity to assess individuals' involvement across different stages of entrepreneurship. One question asks non-entrepreneurs whether they see good opportunities to start a firm in their local area in the next 6 months (Table 3, column B). On this issue, Russia lags well behind almost all of the other benchmark countries: only around $20 \%$ of men and women feel that there are good opportunities for a startup, compared to roughly 30 to $70 \%$ of men and women elsewhere. Not surprisingly, Russians' view that there is a dearth of opportunity strongly affects potential entrepreneurship. Only around $2 \%$ of Russian men and women report that they intend to start a business within the next 3 years. These scores place Russia well below the benchmark countries, especially other BRICS (Table 3, column C).

Table 3

Ease of starting, perceived opportunity for, and intention to start a business

\begin{tabular}{|c|c|c|c|c|c|c|c|c|c|}
\hline \multirow{2}{*}{ Countries } & \multicolumn{3}{|c|}{$\begin{array}{c}\text { A } \\
\text { Easy to start a business }\end{array}$} & \multicolumn{3}{|c|}{$\begin{array}{c}\text { B } \\
\text { Opportunity in local area }\end{array}$} & \multicolumn{3}{|c|}{$\begin{array}{c}\mathrm{C} \\
\text { Intend to start a business }\end{array}$} \\
\hline & Men & Women & $\begin{array}{l}\text { Ratio } \\
\text { W/M }\end{array}$ & Men & Women & $\begin{array}{l}\text { Ratio } \\
\text { W/M }\end{array}$ & Men & Women & $\begin{array}{l}\text { Ratio } \\
\text { W/M }\end{array}$ \\
\hline $\begin{array}{l}\text { Russian } \\
\text { Federation }\end{array}$ & $33.1 \%$ & $22.2 \%$ & 0.7 & $22.3 \%$ & $23.3 \%$ & 1.0 & $2.1 \%$ & $2.3 \%$ & 1.1 \\
\hline \multicolumn{10}{|l|}{$\begin{array}{l}\text { W. Europe / } \\
\text { U. S. }\end{array}$} \\
\hline \multirow{4}{*}{$\begin{array}{l}\text { France } \\
\text { Germany } \\
\text { U. K. } \\
\text { U. S. }\end{array}$} & $35.9 \%$ & $35.5 \%$ & 1.0 & $43.8 \%$ & $26.5 \%$ & 0.6 & $23.6 \%$ & $14.1 \%$ & 0.6 \\
\hline & $56.0 \%$ & $49.5 \%$ & 0.9 & $45.7 \%$ & $37.9 \%$ & 0.8 & $8.2 \%$ & $3.5 \%$ & 0.4 \\
\hline & $59.4 \%$ & $46.0 \%$ & 0.8 & $48.4 \%$ & $39.5 \%$ & 0.8 & $9.4 \%$ & $5.3 \%$ & 0.6 \\
\hline & $48.5 \%$ & $68.2 \%$ & 1.4 & $74.0 \%$ & $65.7 \%$ & 0.9 & $12.8 \%$ & $11.6 \%$ & 0.9 \\
\hline \multicolumn{10}{|l|}{ Visegrad } \\
\hline \multirow{2}{*}{$\begin{array}{l}\text { Poland } \\
\text { Slovak } \\
\text { Republic }\end{array}$} & $24.1 \%$ & $13.5 \%$ & 0.6 & $69.4 \%$ & $67.5 \%$ & 1.0 & $10.2 \%$ & $8.8 \%$ & 0.9 \\
\hline & $74.2 \%$ & $73.8 \%$ & 1.0 & $42.7 \%$ & $32.0 \%$ & 0.7 & $16.6 \%$ & $11.1 \%$ & 0.7 \\
\hline \multicolumn{10}{|l|}{ BRICS } \\
\hline Brazil & $53.0 \%$ & $49.9 \%$ & 0.9 & $33.6 \%$ & $29.3 \%$ & 0.9 & $26.3 \%$ & $25.8 \%$ & 1.0 \\
\hline China & $19.4 \%$ & $13.3 \%$ & 0.7 & $38.2 \%$ & $31.7 \%$ & 0.8 & $16.7 \%$ & $13.8 \%$ & 0.8 \\
\hline India & $18.3 \%$ & $17.6 \%$ & 1.0 & $54.7 \%$ & $44.4 \%$ & 0.8 & $21.8 \%$ & $19.6 \%$ & 0.9 \\
\hline
\end{tabular}


GEM combines the startup stage of entrepreneurial activity - people in the process of starting a business and those with businesses operating less than $31 / 2$ years - into a measure of "total early entrepreneurial activity" (TEA). On this measure, men in Russia outdistance women, $7.3 \%$ to $3.9 \%$, a pattern evident in all the benchmark countries (Table 4, column A). Much of the same pattern holds for other benchmark countries; but the difference with other BRICS is again notable. On average, about twice as many men, and more than twice as many women in BRIC countries are engaged in business startups, compared to men and women in Russia.

Table 4

Entrepreneurial activity

\begin{tabular}{|c|c|c|c|c|c|c|}
\hline \multirow{2}{*}{ Countries } & \multicolumn{3}{|c|}{$\begin{array}{l}\text { A. \% Engaged in total early } \\
\text { entrepreneurial activity (TEA) }\end{array}$} & \multicolumn{3}{|c|}{$\begin{array}{c}\text { B. \% Operating } \\
\text { an established business }\end{array}$} \\
\hline & Men & Women & Ratio W/M & Men & Women & Ratio W/M \\
\hline Russian Federation & $7.3 \%$ & $3.9 \%$ & 0.5 & $5.2 \%$ & $4.6 \%$ & 0.9 \\
\hline \multicolumn{7}{|l|}{ W. Europe / U. S. } \\
\hline \multirow{4}{*}{$\begin{array}{l}\text { France } \\
\text { Germany } \\
\text { U. K. } \\
\text { U.S. }\end{array}$} & $7.0 \%$ & $5.3 \%$ & 0.8 & $3.1 \%$ & $1.8 \%$ & 0.6 \\
\hline & $6.6 \%$ & $3.3 \%$ & 0.5 & $9.4 \%$ & $5.5 \%$ & 0.6 \\
\hline & $11.1 \%$ & $5.4 \%$ & 0.5 & $8.8 \%$ & $4.0 \%$ & 0.5 \\
\hline & $17.7 \%$ & $13.6 \%$ & 0.8 & $10.4 \%$ & $5.4 \%$ & 0.5 \\
\hline \multicolumn{7}{|l|}{ Visegrad } \\
\hline \multirow{2}{*}{$\begin{array}{l}\text { Poland } \\
\text { Slovak Republic }\end{array}$} & $6.0 \%$ & $4.5 \%$ & 0.8 & $15.6 \%$ & $10.4 \%$ & 0.7 \\
\hline & $15.2 \%$ & $9.0 \%$ & 0.6 & $6.2 \%$ & $3.0 \%$ & 0.5 \\
\hline \multicolumn{7}{|l|}{ BRICS } \\
\hline Brazil & $18.5 \%$ & $17.3 \%$ & 0.9 & $23.4 \%$ & $17.2 \%$ & 0.7 \\
\hline China & $11.4 \%$ & $9.3 \%$ & 0.8 & $3.7 \%$ & $2.6 \%$ & 0.7 \\
\hline India & $14.0 \%$ & $8.7 \%$ & 0.6 & $8.9 \%$ & $5.0 \%$ & 0.6 \\
\hline
\end{tabular}

For TEA entrepreneurs, questions also include the motives that prompted people to start businesses, focusing on two general though not mutually exclusive reasons - necessity or opportunity. Necessity primarily involves the inability to find other paid work, while opportunity reflects a desire to be independent or to increase one's income. The results [Bosma, Kelley, 2019: 23-24] show that the necessity motive is more common in countries with lower levels of national income. That is reflected in the data, as necessity looms larger among respondents in Russia and the other BRICS than it does in West European countries and the U. S. [Elam et al., 2019: 100 - 101]. (The data are not shown here.)

In nearly all cases, women are more likely than men to say necessity, and the rate for Russian women is higher at $51.2 \%$ than all other benchmark countries. This can prove to be an inhibiting factor in SME development, since opportunitydriven motivation tends to spur business growth, while necessity-driven motives tend to do the opposite [Verkhovskaia et al., 2020: 60]. However, initial startup decisions are often driven by both types of motives, and opportunity tends to replace necessity as businesses become more established [Williams, 2008].

Survey responses on established businesses, those more than $31 / 2$ years old, resemble those for TEA. The $5.2 \%$ participation rate for Russian men is lower than 
most of their peers, while Russian women's participation rate is somewhat closer to the average for other benchmark countries (Table 4, column B). But the Russian case is closer to gender equality, with the ratio of women to men at 0.9 .

Overall, men and women in Russia seem very favorable to business as a career and a high-prestige occupation, and their views are similar to those in many other benchmark countries. But the data suggest that starting a business in Russia poses a difficult task in citizens' minds. Only about a third of Russian men see it as easy; and only about $20 \%$ of women say the same (Table 3, column A). Russians are relatively low on perceived opportunity, on intentions to launch a business; and on early and established entrepreneurial activity. And this raises questions about the context for starting up and running a business.

\section{Barriers to entrepreneurship}

Federal programs to overcome barriers and spur SME growth predate President Putin's elevation of SMEs as a national priority. These have involved subsidies to regional governments to establish business incubators and provide start-up grants, specialized training, assistance in securing leases and new equipment, and other supportive measures [Iakovleva et al., 2013]. But the SME sector, as Putin noted in 2018, has remained relatively underdeveloped. And there has been a continuing gender gap in entrepreneurship. Few government programs have focused specifically on women, and where women-oriented programs do exist, they have mostly been sponsored by Russian NGO's, international donors, and/or some western countries [Izyumov, Razumnova, 2000] $]^{5}$.

Thus, reducing barriers to starting new enterprises and to female entrepreneurship remain as major tasks for Russia. With respect to obstacles facing new SMEs, GEM's expert assessments provide a window onto elements of the ecosystem that are especially problematic. Experts' responses are combined into scales measuring whether countries encourage the development of small and medium-sized businesses. And a summary of the ratings, the "National Entrepreneurship Context Index" (NECI), combines scores on 12 key framework conditions, covering factors such as the level of government support and favorable policies; access to finance; and openness of the local environment (i.e., whether there is a level playing field for business startups), among others (Table 5, column E).

Russian expert ratings in 2019 were lower than those for benchmark countries on several key issues. Russia's national team assigned a negative mark (below 5 on a scale running from 1 to 9; Table 5, columns A-D) to all areas except for physical infrastructure and internal market dynamics. The team viewed government policy as the most important negative factor - the overgrown bureaucracy, high taxes coupled with harsh administration, frequent changes of the rules of the game, and more. Problems with corruption and lack of access to capital were also rated as serious concerns.

\footnotetext{
${ }^{5}$ A notable exception is the training program "Mama Entrepreneur", organized by Opora's Committee on the Development of Women's Entrepreneurship. Offered in many localities, the program enjoys a partnership with the state, as its graduates are specifically cited as eligible for credit in the Federal Corporation MSP (Small and Medium Sized Enterprise)'s special program of credit guarantees for women entrepreneurs.
} 
Accordingly, we will turn our attention to Russian entrepreneurs' interactions with state agencies and officials (including experiences with corruption), to gaining access to financing, and to the question of gender differences in these areas.

Table 5

Expert ratings of economic/institutional context for SMEs (2019)

\begin{tabular}{|c|c|c|c|c|c|}
\hline Countries & $\begin{array}{c}\text { A } \\
\text { Entrepreneurial } \\
\text { financing }\end{array}$ & $\begin{array}{c}\text { B } \\
\text { Government } \\
\text { policies: } \\
\text { Support \& } \\
\text { relevance } \\
\end{array}$ & $\begin{array}{c}\text { C } \\
\text { Government } \\
\text { policies: Taxes } \\
\text { and } \\
\text { bureaucracy } \\
\end{array}$ & $\begin{array}{l}\mathrm{D} \\
\text { Burdens or } \\
\text { entry } \\
\text { regulations }\end{array}$ & $\begin{array}{c}\mathrm{E} \\
\text { National } \\
\text { Entrepreneur- } \\
\text { ship Context } \\
\text { index } \\
\end{array}$ \\
\hline $\begin{array}{l}\text { Russinan } \\
\text { Federation }\end{array}$ & 3.30 & 3.74 & 3.30 & 3.17 & 4.6 \\
\hline \multicolumn{6}{|l|}{ W. Europe / U. S. } \\
\hline \multirow{4}{*}{$\begin{array}{l}\text { France } \\
\text { Germany } \\
\text { U. K. }\end{array}$} & 4.68 & 5.86 & 5.34 & 3.92 & 5.6 \\
\hline & 4.75 & 4.28 & 4.34 & 5.14 & 5.4 \\
\hline & 4.98 & 3.39 & 4.89 & 4.44 & 4.9 \\
\hline & 5.95 & 4.17 & 4.68 & 4.74 & 6.0 \\
\hline \multicolumn{6}{|l|}{ Visegrad } \\
\hline \multirow{2}{*}{$\begin{array}{l}\text { Poland } \\
\text { Slovak Republic }\end{array}$} & 5.24 & 4.88 & 3.15 & 4.29 & 5.2 \\
\hline & 4.79 & 2.41 & 2.89 & 4.57 & 4.3 \\
\hline \multicolumn{6}{|l|}{ BRICS } \\
\hline \multirow{3}{*}{$\begin{array}{l}\text { Brazil } \\
\text { China } \\
\text { India }\end{array}$} & 4.80 & 2.77 & 2.03 & 3.65 & 4.2 \\
\hline & 4.60 & 4.79 & 4.46 & 4.41 & 5.6 \\
\hline & 5.65 & 6.33 & 4.71 & 5.26 & 6.2 \\
\hline
\end{tabular}

Responses for questions in Columns A-D are scaled 1 to 9 , where $1=$ most negative, and $9=$ most positive assessment. Column $\mathrm{E}$ is scaled 1 to 10 , where $1=$ most negative, and $10=$ most positive score. Note that the scale in column E includes several other indicators besides those in columns A-D.

Source: [Bosma, Kelley, 2019: 58-59, 65-114].

\section{Interactions with state agencies and officials}

Entrepreneurs' accounts of red tape and confusing, conflicting or changing regulations are commonplace. While the past two decades have witnessed efforts to reduce bureaucratic burdens, such as simplifying registration procedures and imposing moratoria on inspections, some officials have quietly introduced new forms of reports and instructions [Putin, 2018b]. These include, for example, informal or unplanned inspections to circumvent limits on scheduled or formal inspections. This adds to other, persistent bureaucratic obstacles, involving various permits, accreditations, fire safety, sanitary conditions, office space, and interaction with tax officials [Krylova, 2018].

The 2019 World Bank Enterprise Survey of business owners and senior managers offers additional evidence on this score, and on potential differences in male and female owners/managers' interactions with government agencies. It asks respondents to report what percentage of time in a typical week over the past year was spent dealing with government regulations (taxes, licensing, completing forms, etc.). Russia's 
score of $5.6 \%$ (for small, medium and large enterprises combined) is within the range for the Visegrad countries and the BRICS, as scores in these benchmark countries ranged from the low single digits to nearly $17 \%$ (Western European countries and the U. S. were not included in the study). And in virtually all the cases gender differences are minimal.

But this picture would not be complete without considering the extent to which bureaucratic contacts convey the threat of predatory behavior on the part of officials. For example, the 2019 Enterprise Survey asks owners/managers whether firms like theirs make informal payments or give gifts to public officials to "get things done" with respect to customs, taxes, licenses, regulations, services, etc. Here, the Russian case proves an outlier: $26.8 \%$ of firms acknowledged bribe requests or payments, while the scores in most benchmark countries ranged from around $2 \%$ to roughly $12 \%$.

For Russia and for most benchmark countries, men and women report roughly identical responses regarding the role of extra payments or gifts as part of doing business [Compare economies..., 2020]. Although some studies argue that Russian female entrepreneurs are less inclined to engage in corrupt practices [Krylova, 2018], the Enterprise Survey data suggest that for those engaged in business ventures, adaptation - seeing to the survival of your business - compels similar behavior. What we cannot assess, however, is whether concerns about corruption have a differential gender impact on decisions to take initial steps toward entrepreneurship.

\section{Access to financing}

The availability of affordable capital is another major concern for entrepreneurs in Russia, as well as for their counterparts in most benchmark countries (Table 5, column A). Research on Russia notes that it can be particularly difficult to get external financing (i. e., funds from formal institutions or venture capitalists rather than using one's own or family resources). Russia reportedly has fewer overall financial intermediaries available to provide funds than do other middle-to-high-income countries, so external financing comes predominantly from banks [Gorshkov, 2017]. And some research on SMEs reports that banks, mostly government-owned, tend to be relatively risk-averse when it comes to startups, preferring to fund more established firms instead [Iakovleva et al., 2013]. Prior research also notes other factors that dissuade entrepreneurs from seeking external sources of financing: high interest rates; complicated application procedures; fear of predation by some lenders; and more [Gorshkov, 2017] ${ }^{7}$.

Cross-national evidence on gender and SMEs notes that women entrepreneurs are less likely than men on average to seek external financing, due to more reluctance than men to take on debt; owning less collateral to put up for a loan; and launching and running somewhat smaller operations than men do (with fewer employees and lower revenue), requiring less up-front financing.

\footnotetext{
${ }^{6}$ The data for Russia, Poland, and Slovakia are for 2019; for India, 2014; for China, 2012, for Brazil, 2009.

${ }^{7}$ Note, though, that bankers and officials dealing with SMEs who were interviewed by Iakovleva, Solesvik and Trifilova expressed concern because many applicants for funding lacked systematic data on their firm's operations and well-grounded projections of upcoming business activity, and/or had misfiled application documents [Iakovleva et al., 2013]. And they noted instances when funding was available but there were too few completed applications to support.
} 
While evidence is rather sparse on gender differences in actual applications, loans received, and interest rates, fieldwork in Nizhny Novgorod and Moscow by Iakovleva, Solesvik and Trifilova suggests that women are less likely to apply for external funding [Iakovleva et al., 2013]. If they do apply, women are reportedly as likely as men to receive it. The authors do find one important exception, however: bankers who were interviewed for the project expressed reluctance to lend to single mothers with small children, out of concern that the ventures would not succeed.

Expert and owner/manager survey responses thus indicate that the ecosystem poses some serious challenges for budding entrepreneurs. While the context in many benchmark countries is also rated as relatively poor (Table 5), the ratings suggest that the context is especially difficult for SMEs in Russia. They also suggest that for many aspects of the context, men and women entrepreneurs face similar challenges.

\section{Women, legal protections, and political empowerment}

Other elements of the context can, however, have differential effects for women and men entrepreneurs - especially elements related to the legal system and to political empowerment. For example, demonstrate that countries ranking high on both rule of law and women's political empowerment have the highest rates of female entrepreneurship [Goltz et al., 2015]. The authors suggest that greater political representation can increase access to key resources for women entrepreneurs and can potentially reduce the odds of discrimination by financial, legal and regulatory institutions. It can also generate networks of officials who might be particularly responsive to questions and concerns from female business owners. In addition, stronger rule of law can foster a more level playing field for SMEs, and reduce the odds of corruption.

As Goltz et al. demonstrate, Russia scores well below most benchmark countries on both political empowerment for women and rule of law [ibid.]. Additional evidence on the legal system shows Russia with fewer protections for women in the economic sphere than almost all other benchmark states.

\section{Conclusion}

In sum, compared to peers in the benchmark countries, both genders in Russia face more serious obstacles to launching a new business, from the availability of financing to internal market openness. Russia's gender patterns, however, are somewhat distinctive: Russian women, unlike their benchmark counterparts, are just as likely as men to perceive (lack of) opportunity in their local area and to express similar (relatively low) levels of intention to start a business. But they do not follow through, trailing men as early-stage entrepreneurs; and they lack self-confidence in their ability to start and run a business to a greater extent than their benchmark counterparts. These gender patterns appear particularly anomalous in that Russian women have high levels of educational and labor force achievement and express a high regard for entrepreneurship as a good and as a high-status career.

Some recent statements and initiatives by the Russian federal government suggest an increasing recognition of the value of encouraging more women to become entrepreneurs. At the 2017 BRICS conference, President Putin (as cited in RIA "Novosti", 2017) acknowledged that many countries around the world call for the development 
of women's entrepreneurship, which he labeled "an important, correct thing". The Federal Corporation MSP (Small and Medium Sized Enterprises), an agency founded in 2015 to boost the SME sector, introduced a special program of credit guarantees in 2017 for women entrepreneurs. In addition, Russia's National Strategy for Women 2017-2022 includes a call for state support for women in the SME sector.

These steps have, however, met with a marked slowdown in the implementation of Russia's national projects, a rebooting that began in the context of slow economic growth in 2019 and was followed by the COVID pandemic with its devastating impact on economic well-being and the SME sector ${ }^{8}$. Budgetary shortfalls make it all the more imperative that federal programs not waste resources, that they be welldesigned and serve to accelerate SME growth, with special attention directed toward women. Here, future public policy-oriented research can assist in ascertaining the most effective strategies.

One question, for example, is how regional and local conditions affect individuals' perceptions of business opportunities and engagement in entrepreneurship. Given the diversity across Russia's federal subjects in income levels, urbanization, employment, and quality of governance, and other conditions, systematic cross-region research can highlight the key factors that generate higher rates of entrepreneurship and possibly different ratios of women to men business owners. Such analyses could identify areas and models that have been more successful in promoting entrepreneurship, and in encouraging women to launch businesses 9 .

Another question relates to the incentives for individuals to start a business. Some research shows, for example, that women tend to cite flexibility of working conditions and hours as a main incentive for starting a business, to allow a balance between work and family life. And flexibility is seldom if ever mentioned as a motive by men with similar qualifications [DeMartino, Barbato, 2003]. If it is central to women's motives, it would help to explain why women-owned and operated businesses tend to be smaller in scale, since small size would afford an owner greater flexibility.

In addition, future research could explore the implications of digitalization for SMEs in general and for women's entrepreneurship. Some studies have noted the difficulties small businesses face in keeping technology updated, and in having sufficient staff to manage online reporting, advertising and other tasks (see, e. g.: [The Missing Entrepreneurs..., 2019]). But there is also another side to digitalization: the provision of access to ecommerce platforms for SMEs to sell their goods and services online. The emergence of multiple such platforms in other countries in recent years seems especially likely to benefit smaller and women-owned businesses. Russia's retail sales online were expanding rapidly pre-pandemic and now have soared due to the coronavirus. For women to take advantage of this source of potential growth, training programs like the Women Digital Academy, offered jointly by Opora's Committee on the Development of Women's Entrepreneurship and Google Russia, could play

\footnotetext{
${ }^{8}$ As of this writing, in December 2020, the list of national projects has been reduced, and their target dates have been moved from 2024 to 2030. The national project to expand SMEs has been retained, with a 2030 target date [Rubchenko, 2020].

${ }^{9}$ One recent study, for example, shows that improvements in the regulatory environment and a decrease in administrative barriers lead to a healthier SME sector [Krylova, 2019: 44 —71].
} 
a key role. That program provides a free series of webinars across a host of issues related to exploiting the internet as an important aspect of entrepreneurial activity.

However, analysis by the OECD suggests that any single initiative that tackles one particular issue is less effective than a multi-faceted set of policies implemented together [ibid.]. Such a package would include coordinating policies across banks, taxation, labor, and health; publicizing stories about entrepreneurs who started from scratch; publicizing government programs and how to access them and focusing the information in media outlets and other venues where women are most likely to see it; using diverse forms of outreach to get information to women about opportunities for training/consultation; and promoting support networks for women entrepreneurs. Publicity — throwing a spotlight — on existing opportunities as well as expanding those opportunities is crucial: surveys suggest that women generally are unaware of the options available to them.

Finally, greater efforts to tackle gender stereotypes could open a wider array of entrepreneurial opportunities for women ${ }^{10}$. That especially holds in STEM fields, where the government places a high priority on technological innovation and its contribution to economic policy [Ilimbetova, 2020; Savinskaia, Lebedeva, 2020]. The expansion of digital work from home could encourage women to start businesses in areas such as computer science and engineering.

All of these proposals may seem ambitious, but improvements in the context of entrepreneurship could deliver big dividends. Expanding the SME sector and drawing more women into starting their own businesses, can spur economic growth, employment and economic well-being. The population, particularly women, regard entrepreneurship as a good and prestigious career, as much as or more so than in the benchmark countries we studied. That foundation suggests that a concerted effort to encourage women entrepreneurs and to improve the context for SMEs could unleash considerable pent-up energy and talent.

\section{References}

Acs, Z., Desai, S., Klapper, L. (2008) What does "entrepreneurship" data really show?, Small Business Economics, vol. 31, no. 3, pp. 265-281.

Bosma, N., Kelley, D. (2019) Global Entrepreneurship Monitor: 2018/2019 Global Report, London, UK: Global Entrepreneurship Research Association, London School of Business, available from https://www.gemconsortium.org/file/open?fileId=50213 (accessed 11.11.2020).

Bosma, N. et al. (2020) Global Entrepreneurship Monitor 2019/2020 Global Report, London, UK: Global Entrepreneurship Research Association, available from https://www.gemconsortium.org/report/gem-2019-2020-global-report (accessed 11.11.2020).

Business (2014), Levada Center, 13 November, available from https://www.levada.ru/ en/2014/11/13/business (accessed 30.07.2019).

Compare economies and topic (2020), Enterprise Surveys, World Bank, available from https://www.enterprisesurveys.org/en/custom-query (accessed 26.10.2020).

\footnotetext{
${ }^{10}$ As Voronina notes, countering stereotypes would involve a shift in Russian policy, which currently places more emphasis on women as mothers [Voronina, 2020: 8].
} 
DeMartino, R., Barbato, R. (2003) Differences between women and men MBA entrepreneurs: exploring family flexibility and wealth creation as career motivators, Journal of Business Venturing, vol. 18, iss. 6, pp. 815-832, available from https://www.sciencedirect.com/ science/article/pii/S088390260300003X (accessed 18.11.2020).

Development of Women's Entrepreneurship is a Recognized Global Trend (2017), 31 May, available from http://eawfpress.ru/en/development-of-women-s-entrepreneurship-is-aglobal-trend/ (accessed 18.09.2017).

Djankov, S. et al. (2005) Who are Russia's entrepreneurs?, Journal of the European Economic Association, vol. 3, iss. 2-3, pp. 587-597.

Elam, A. et al. (2019) Global Entrepreneurship Monitor: 2018/2019 Women's Entrepreneurship Report, London, UK: Global Entrepreneurship Research Association, London Business School, available from https://www.gemconsortium.org/file/ open?fileId=50405 (accessed 11.11.2020).

Feinberg, A. (2019) Rosstat vpervye raskryl doliu malogo i srednego biznesa v èkonomike [Rosstat for the first time revealed the shares of small and medium-sized businesses in the economy], Ekonomika, 5 fevralia, available from https://www.rbc.ru/economics/ 05/02/2019/5c5948c59a794758389cfdf7?from=newsfeed (accessed 11.11.2020).

Goltz, D. et al. (2015) Political empowerment, rule of law and women's entry into entrepreneurship, Journal of Small Business Management, vol. 53, iss. 3, pp. 605-626, available from https://onlinelibrary.wiley.com/doi/10.1111/jsbm.12177 (accessed 14.11.2020).

Gorshkov, V. (2017) Financial inclusion in Russia: challenges for the promotion of longterm savings and investment, Journal of Comparative Economic Studies, vol. 12, pp. $121-133$.

Iakovleva, T., Solesvik, M., Trifilova, A. (2013) Financial availability and government support for women entrepreneurs in transitional economies: cases of Russia and Ukraine, Journal of Small Business and Enterprise Development, vol. 20, iss. 2, pp. 314-340, available from https://core.ac.uk/download/pdf/52065235.pdf (accessed 08.11.2020).

Ilimbetova, A. A. (2020) Uchastie zhenshchin Rossii v STEM-biznese [Participation of Russian women in STEM business], Zhenshchina $v$ rossiüskom obshchestve, no. 2, pp. $52-61$.

Izyumov, A., Razumnova, I. (2000) Women entrepreneurs in Russia: learning to survive the market, Journal of Developmental Entrepreneurship, vol. 5, iss. 1, pp. 1-19.

Kolesnikov, A., Volkov, D. (2019) Pragmatic paternalism: the Russian public and the private sector, Carnegie Moscow Center, available from https://carnegie.ru/commentary/78155 (accessed 24.01.2019).

Krylova, Yu. (2018) Corruption and the Russian Economy: How Administrative Corruption Undermines Entrepreneurship and Economic Opportunities, London: Routledge.

Modest Growth; Focus on Informality: Russia Economic Report (2019), World Bank Group, June, available from http://hdl.handle.net/10986/31933 (accessed 23.11.2020).

Pin'kovetskaia, Iu. (2019) Predprinimatel'skaia aktivnost' zhenshchin v sovremmenor ékonomike [Entrepreneurial activity of women in the modern economy], Zhenshchina $v$ rossiükom obshchestve, no. 1, pp. 40-51.

Poll: Russians are certain women's business talents are in no way inferior to men's (2016), TASS, 4 March, available from http://tass.ru/en/society/860623 (accessed 05.10.2018).

Putin, V. (2018a) Presidential Address to the Federal Assembly, 1 March, available from http://en.kremlin.ru/events/president/news/56957 (accessed 12.11.2020).

Putin, V. (2018b) Small Business as a National Project Forum, 23 October, available from http://en.kremlin.ru/events/president/news/58879 (accessed 12.11.2020).

Rubchenko, M. (2020) Putin otlozhil srok realizatsii natsproektov [Putin postponed the deadline for the implementation of national projects], Vedomosti, 14 July, available 
from https://www.vedomosti.ru/economics/articles/2020/07/13/834504-prezident-otlozhilnatsproekti (accessed 05.12.2020).

Russia: Modernising the Economy (2013), Paris: OECD Publishing.

Russia's small businesses contribute just $20 \%$ of economy (2020), The Moscow Times, 28 January, available from https://www.themoscowtimes.com/2020/01/28/russiassmall-businesses-contribute-20-percent-russia-economy-a69063 (accessed 05.02.2020).

Savinskaia, O. B., Lebedeva, N. V. (2020) Pochemu zhenshchiny ukhodiat iz STEM: rol' stereotipov [Why women leave STEM: the role of stereotypes], Zhenshchina $v$ rossiüskom obshchestve, no. 2, pp. 62-75.

The Missing Entrepreneurs: Policies for Inclusive Entrepreneurship (2019), Paris: OECD Publishing, available from https://www.oecd.org/industry/the-missing-entrepreneurs43c2f41c-en.htm (accessed 05.11.2020).

Tsyganova, T., Shirokova, G. (2010) Gender differences in entrepreneurship: evidence from GEM data, Organizations and Markets in Emerging Economies, vol. 1, no. 1, pp. 120 -141.

Verkhovskaia, O. R. et al. (2020) Global'ny̌ monitoring predprinimatel'stva: Rossiia 2019/2020: Natsional'ny̌̌ otchët [Global entrepreneurship monitoring: Russia 2019/2020: National report], available from https://www.gemconsortium.org/ file/open?fileId=50488 (accessed 11.11.2020).

Voronina, O. A. (2020) Post-Pekin: rossiǔskaia gendernaia politika v mezhdunarodnom kontekste [Post-Beijing: Russian gender policy in the international context], Zhenshchina $v$ rossiüskom obshchestve, no. 3, pp. 3-13.

Williams, C. (2008) Beyond necessity-driven versus opportunity-driven entrepreneurship: a study of informal entrepreneurship in England, Russia and Ukraine, International Journal Entrepreneurship and Innovation, vol. 9, iss. 3, pp. 1-9.

Women, Business and the Law: Dataset (2020), World Bank, available from https://datacatalog. worldbank.org/dataset/women-business-and-law (accessed 05.11.2020).

Статья поступила 14.01.2021 2.

\section{Information about the authors / Информация об авторах}

Nechemias Carol - Dr. Sc., Associate Professor Emerita of Political Science and Public Policy, School of Public Affairs, Pennsylvania State University, Harrisburg, Middletown, PA, USA, c4n@psu.edu (почетный доктор политических наук и государственной политики, Школа по связям с общественностью, Университет штата Пенсильвания, г. Гаррисберг, Миддлтаун, США).

Bahry Donna - Dr. Sc. (Political Science), Professor at Political Science Department, Pennsylvania State University, University Park, USA, DBahry@psu.edu (доктор политических наук, профессор кафедры политологии, Университет штата Пенсильвания, Университетский парк, США). 